\title{
ピッティング損傷を受けた表面改質処理ステンレス鋼の曲げ痑労強度
}

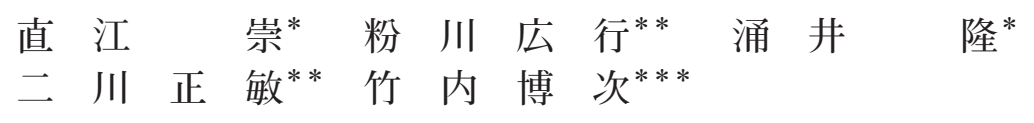

\section{Bending Fatigue Strength of Surface Modified Stainless Steel with Pitting Damage}

\author{
by
}

\author{
Takashi NAOE ${ }^{*}$, Hiroyuki Kogawa ${ }^{* *}$, Takashi WakuI ${ }^{*}$, \\ Masatoshi FutAKawa $^{* *}$ and Hirotsugu TAKEUCHI ${ }^{* * *}$
}

\begin{abstract}
A liquid mercury target system for MW-class spallation neutron source is installed in Japan Proton Accelerator Research Complex (J-PARC). High power proton beams bombard the mercury at $25 \mathrm{~Hz}$, the mercury target vessel suffers the repeated stress due to the pressure waves induced by thermal expansion of the mercury. Cavitation will be generated in the propagation of pressure waves, and pitting damage will be formed on the inner wall of the target vessel by the cavitation bubble collapse. In previous research, it was confirmed that the surface hardening treatment is effective to suppress the pitting damage at some level, although crack and/or separation occurred due to poor interface strength. A novel surface modification technique was developed based on the previous research : i.e. double stratified surface modification by plasma nitriding and carburizing. The bending fatigue tests on modified stainless steels with pitting damage were performed. As results, damage suppression and fatigue limit improvement due to the modification were confirmed.
\end{abstract}

Key words : Surface modification, Nitriding, Carburizing, Cavitation erosion, Mercury, Pitting damage, Fatigue degradation

\section{1 緒言}

高強度核破砕パルス中性子源の開発が世界的に実施さ れている，そこでは，核破砕反応に伴う発熱を効率的に除 去するために，核破砕標的として液体水銀を用いる.1) 3) パルス陽子線が入射されると水銀中で瞬時発熱に伴った 膨張波が圧力波となって伝ぱして, 水銀容器に衝撃的荷 重を負荷する。パルス陽子線は繰返し入射され，乤の周 期は，例えばJSNS (Japan Spallation Neutron Source) で は, $25 \mathrm{~Hz}$ である. 著者らは, これまでに水銀ターゲット 容器構造体の健全性に関する研究を進めていく中で, 大 強度パルス陽子線入射時に励起される圧力波の水銀伝ぱ 過程でキャビテーションが生じ, 容器壁面に損傷, いわ ゆるピッティング損傷が付加されることを見出した.4)容 器寿命に対する支配的因子である疲労強度は, ピッティ ング損傷により低下する.5)従って，材料の側面から低下 を軽減するために表面改質技術の適用を試み, その有効 性を衝撃圧力負荷試験打よびキャビテーション崩壊時の 衝撃負荷を模擬した数值解析により評価してきた.6. れらの結果より, 硬い被覆膜や改質層により, ある程度 ピット形成に対する抑制効果を発現できることを確認で きた。しかしながら, 基材との界面強度が不十分のため, 多数回の局所衝撃負荷により界面に沿ったはく離が生じ ることが明らかとなった.8)
本報では，これまでに実施した既存技術による表面改 質处理の評価結果を基に, 新たな階層型表面改質処理技 術を考案している。さらに，階層型表面改質処理を適用 したステンレス鋼に対して，ピッティング損傷特性およ び疲労強度に関する評価試験を行い, 最適な改質条件の 検討を行う。

\section{2 階層型表面改質処理}

ピット形成時に生じる局所衝撃負荷に対する改質層の はく離を抑制するために, オーステナイト系ステンレス 鋼に対して適度な表層厚さに対して硬さを増加させ，表 面改質層硬さが基材值に緩やかに漸近するような表面改 質法として階層型处理を考案した. Fig. 1 に階層型表面 改質处理の概念を示す. 第 1 段階では, 真空容器内にて 炭化水素系ガス雾囲気中でグロー放電を行い，炭素をプ

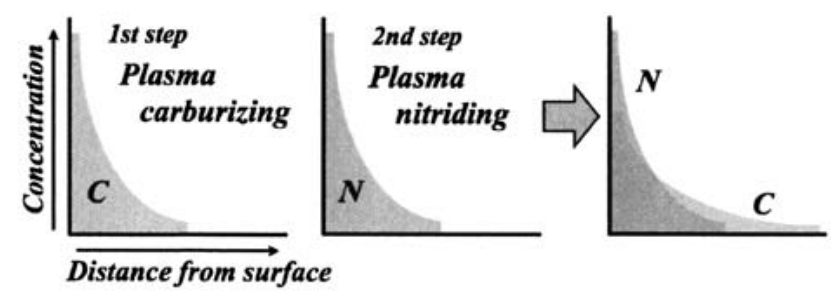

Fig. 1 Concept for double stratified surface modification technique.

$\dagger \quad$ 原稿受理 平成 19 年 8 月 7 日 Received Aug. 7, 2007 C 2008 The Society of Materials Science, Japan

* (独)日本原子力研究開発機構 干 319-1195 茨城県那珂郡東海村, Japan Atomic Energy Agency, Naka-gun, Ibaraki, 319-1195

** 正会員 (独)日本原子力研究開発機構 =319-1195 茨城県那珂郡東海村, Japan Atomic Energy Agency, Naka-gun, Ibaraki, 319-1195

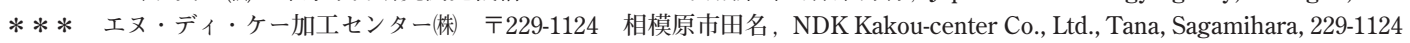


ラズマ化して材料表面より浸透拡散させる. 第 2 段階で は, 同一真空容器内にて浸炭表層に窒素ガス䨌囲気中で グロー放電によりプラズマ化した窒素を浸透拡散させる. このとき，第 1 段階で浸透した炭素は，さらに深く浸透 する．第 1 段階の処理温度は，クロム炭化物の析出を抑 えて効率よく炭素が浸透できる $723 \mathrm{~K}$ ，第 2 段階は，ク口 ム窒化物が析出しにくい $673 \mathrm{~K}$ とし，ステンレス鋼が有す る耐食性を損なわない処理温度とした。以上より，なだ らかに特性が変化する表面改質層を得ることができる。

処理時間については低温では拡散速度が低下すること から，期待する改質層厚さを得るための最適時間を実験 的に検討した. SUS316L（溶体化処理材）にプラズマ浸 炭を $723 \mathrm{~K}$ で $20 \mathrm{~h} ， 673 \mathrm{~K}$ で $31.5 \mathrm{~h}$ ，プラズマ窒化を $673 \mathrm{~K}$ で $80 \mathrm{~h}$ および $190 \mathrm{~h}$ をそれぞれ行い，断面の硬度を測定 した。ここで，硬度はべルコビッチ圧子を用いて $29.4 \mathrm{mN}$ で計測した荷重一深さ曲線の最大深さから算出した硬 度である。硬度分布を Fig. 2 に示す。ここで，表面から の距離 $0 \mu \mathrm{m}$ の硬度は表面での測定值である，浸炭処理 $20 \mathrm{~h}$ および $31.5 \mathrm{~h}$ の全硬化層厚さは，それぞれ $25 \mu \mathrm{m}$, $20 \mu \mathrm{m}$ であった。また，表面の硬度は $31.5 \mathrm{~h}$ でわずかに 高くなった。また，窒化処理 $80 \mathrm{~h}$ および $190 \mathrm{~h}$ での全硬 化層厚さは, $20 \mu \mathrm{m}, 30 \mu \mathrm{m}$ であった。 これらの結果から， 次に示す Harris の実験式 ${ }^{9)}$ を用いて拡散係数の算出を 行った.

$$
D=K^{2} / 2 t
$$

ここで， $D$ は拡散係数， $K$ は全硬化層厚さ, $t$ は処理時 間である。算出した拡散係数を Table 1 に示す。プラズ マ浸炭処理材では，処理温度が $50 \mathrm{~K}$ 上昇することにより 炭素の拡散係数は約 2.5 倍となった. $673 \mathrm{~K}$ では炭素の拡

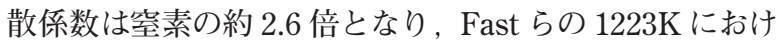

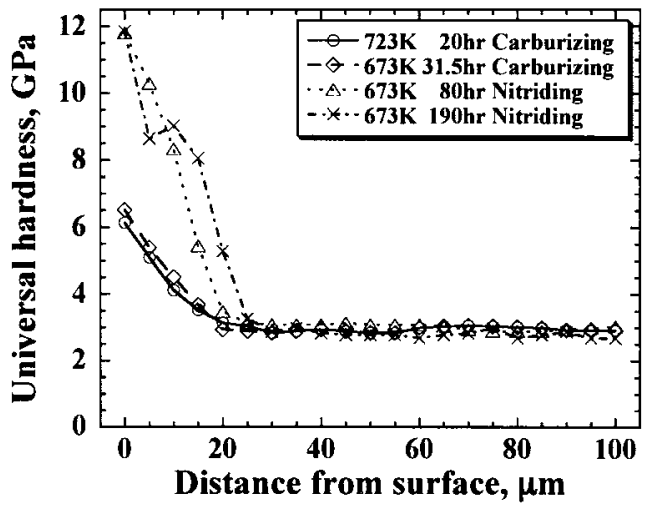

Fig. 2 Cross-sectional hardness distribution for each treatment conditions.

Table 1 Diffusion coefficients of each condition.

\begin{tabular}{cccc}
\hline Treatment & Temp., $\mathrm{K}$ & Time, $\mathrm{h}$ & $\begin{array}{c}\text { Diffusion } \\
\text { coefficient, } \mathrm{cm}^{2} / \mathrm{s}\end{array}$ \\
\hline Plasma carburizing & 723 & 20 & $4.34 \times 10^{-11}$ \\
Plasma carburizing & 673 & 31.5 & $1.76 \times 10^{-11}$ \\
Plasma nitriding & 673 & 80 & $6.94 \times 10^{-12}$ \\
Plasma nitriding & 673 & 190 & $6.58 \times 10^{-12}$ \\
\hline
\end{tabular}

る拡散係数の比較結果 ${ }^{10)}$ と同様の傾向を示した。これら の結果に基づき，著者らが先に実施したピット下部に形 成する応力分布 ${ }^{7)}$ から, 改質層と基材界面での発生応力 を抑えるために，全硬化層厚さを約 $40 \mu \mathrm{m}$ と設定して処 理時間を決定した。即ち，第 1 段階処理時間を $20 \mathrm{~h}$ ，第 2 段階处理時間を $190 \mathrm{~h}$ とした。 Fig. 3 には，本処理条 件で得た階層型表面改質処理の硬度分布を非処理材と共 に示す．第 1 段階で浸炭した炭素は，第 2 段階の窒化処 理過程にも拡散が継続され，窒化による硬さの上昇と炭 素浸入による傾斜的な変化を達成できた。炭素の硬化層 厚さをTable 1 に示す拡散係数を用いて評価すると，約 $50 \mu \mathrm{m}$ となり，ほぼ実験結果と一致する。

\section{3 実験}

\section{$3 \cdot 1$ ピッティング損傷試験}

表面改質処理材のピッティング損傷特性を調べるため に，電磁式衝撃圧負荷試験装置（MIMTM：electroMagnetic IMpact Testing Machine (株振研製 G25-210) によるピッティング損傷試験を行った。装置は，Fig. 4 に示すような水銀を充填した SUS316L 製の円筒容器内に 試料を固定し，電磁力駆動のストライカーを介して水銀 中に衝撃圧を負荷できる。なお，本実験ではキャビテー ションを生じさせるために，負の衝撃圧を負荷した。試 料は, SUS316L およびSUS316 を基材としてプラズマ窒 化処理 (673K 190h)，および皆層型処理（プラズマ浸炭 $723 \mathrm{~K} 20 \mathrm{~h}+$ プラズマ窒化 $673 \mathrm{~K} 190 \mathrm{~h} ）$ を施した $60 \times 60 \times$

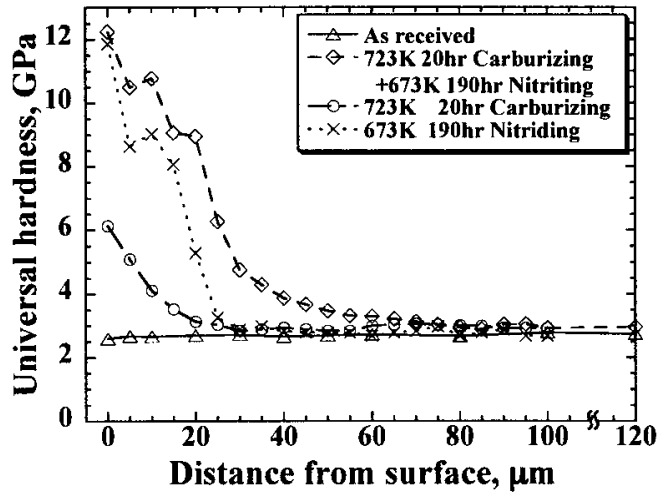

Fig. 3 Cross-sectional hardness distribution for double stratified surface modification and as-received specimens.

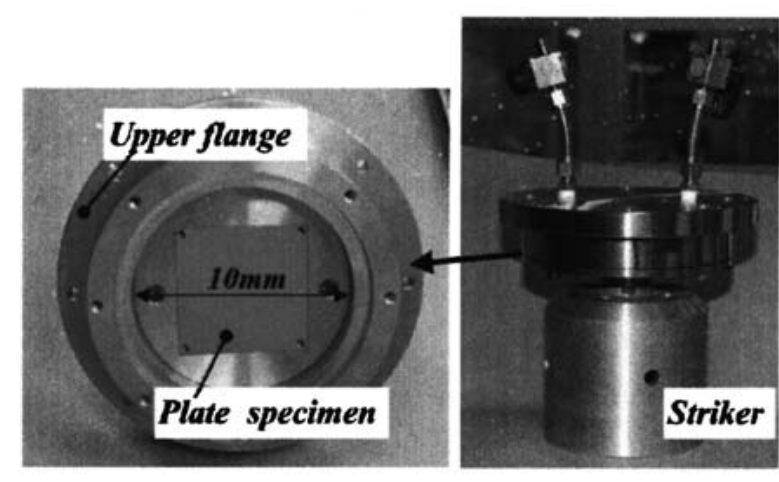

Fig. 4 Mercury chamber for MIMTM pitting damage test. 
$2.5 \mathrm{~mm}^{3}$ の板材である. 負荷圧力を決定する電磁コイルへ の入力パワーは $560 \mathrm{~W}$, 衝撃圧の負荷周波数は $25 \mathrm{~Hz}$ 一定 とした。ここで, 入力パワー $560 \mathrm{~W}$ は，1 MW 相当の陽 子線入射時に形成される損傷を再現することが確認され ている. ${ }^{11}$ 衝撃圧の負荷回数は，これまでの実験によりプ ラズマ窒化材に打いて改質層の残存が確認されなかった $10^{7}$ 回とした。な扔, $10^{7}$ 回以下のピッティング損傷形態

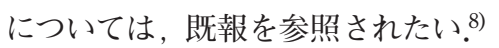

試験後, 超音波洗浄により水銀を除去し，レーザ一顕 微鏡（㑣）Keyence 製 VK-9510）により試料表面および 断面を観察した.

\section{$3 \cdot 2$ 疲労試験}

表面改質, さらにピッティング損傷による疲労強度の 変化を調べるために, SUS316L および表面改質处理を施 した試料に対して曲げ疲労試験を行った。試験は, 高サ イクル疲労試験機（株振研製 G21-110S）によりスパン $30 \mathrm{~mm}$ の荷重制御，正弦波負荷として，大気中片振り 3 点曲げで行った. 試験片形状は, 非損傷材打よびピッティ ング損傷付加後の板材から切り出した $4 \times 60 \times 2.5 \mathrm{~mm}^{3}$ の 短冊型であり, 最外皮応力の最小／最大で表される応力 比は 0.1 とした。また，負荷周波数は, $100 \mathrm{~Hz}$ とした. なお，SUS316Lに対する試験により， $1 \mathrm{~Hz}$ 打よび $100 \mathrm{~Hz}$ では周波数依存性が無いことを確認している. 試験中は, レーザー変位計により変位計測を行い, 最大変位が $4 \mathrm{~mm}$ を超えた場合を破断と定義し, 繰返し数 $10^{7}$ 回で破断し ない場合を未破断とした。また，疲労破断後の破面を， SEM（株 Keyence VE-7800）を用いて観察し, 表面改 質打よびピッティング損傷付加による疲労破面の差異を 比較した。

\section{4 実 験 結 果}

$4 \cdot 1$ 表面改質によるピッティング損傷形態の変化

レーザー顕微鏡により観察した非損傷材, および $10^{7}$ 回損傷試験後の試料表面写真を Fig. 5 に示す. 試料は, 改質处理前に鏡面研磨を施しているが，プラズマ窒化お よび階層型处理後では, $3 \mu \mathrm{m}$ 程度の起伏が確認された。 これは，窒化打よび浸炭処理により析出した化合物層で あり, この化合物層が析出する際の体積膨張に起因する ひずみにより表層部には圧縮残留応力が生じ, 硬度の上 昇が得られたと推測できる。試験後の SUS316L およびプ ラズマ窒化では, 試験前の表面を確認できないほどの損 傷が形成された。一方，階層型处理は試験前の表面と大 きな差は見られなかった，損傷の程度を比較するために， Fig. 5 に示した損傷後の 3 次元画像を Fig. 6 に示す. ま た, 図中矢印の区間で計測した深さプロファイルを Fig. 7 に示す. SUS316Lは，観察領域に対してほぼ均一に損傷 が形成されている，損傷深さは約 $25 \mu \mathrm{m}$ であり，塑性変 形が支配する潜伏期を経て, 質量減少が生じる定常期に 移行していると考えられる.プラズマ䇪化は, 過去に行っ た $10^{6}$ 回損傷試験では，ほとんど損傷が形成されず，潜 伏期の増長効果が見られた ${ }^{8}$ が，107 回試験後では, 表面 あらさの起伏が激しく，局所的な壞食が確認された。損 傷深さは約 $65 \mu \mathrm{m}$ であり, SUS316L の約 2.5 倍であった.
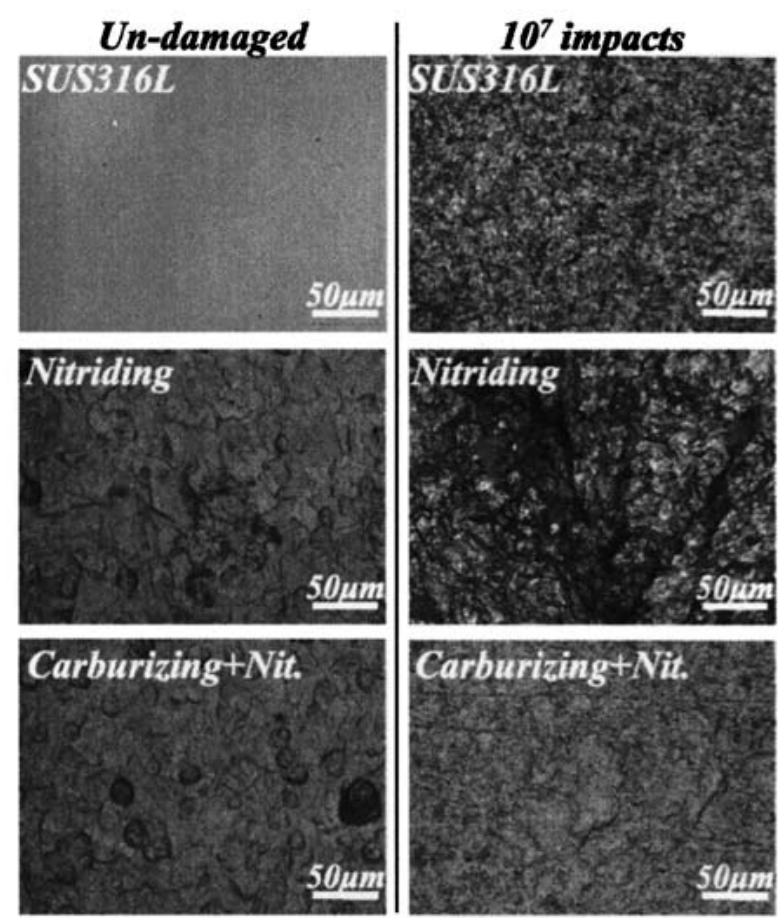

Fig. 5 Micrograph of specimen surface for before and after $10^{7}$ impacts by MIMTM.
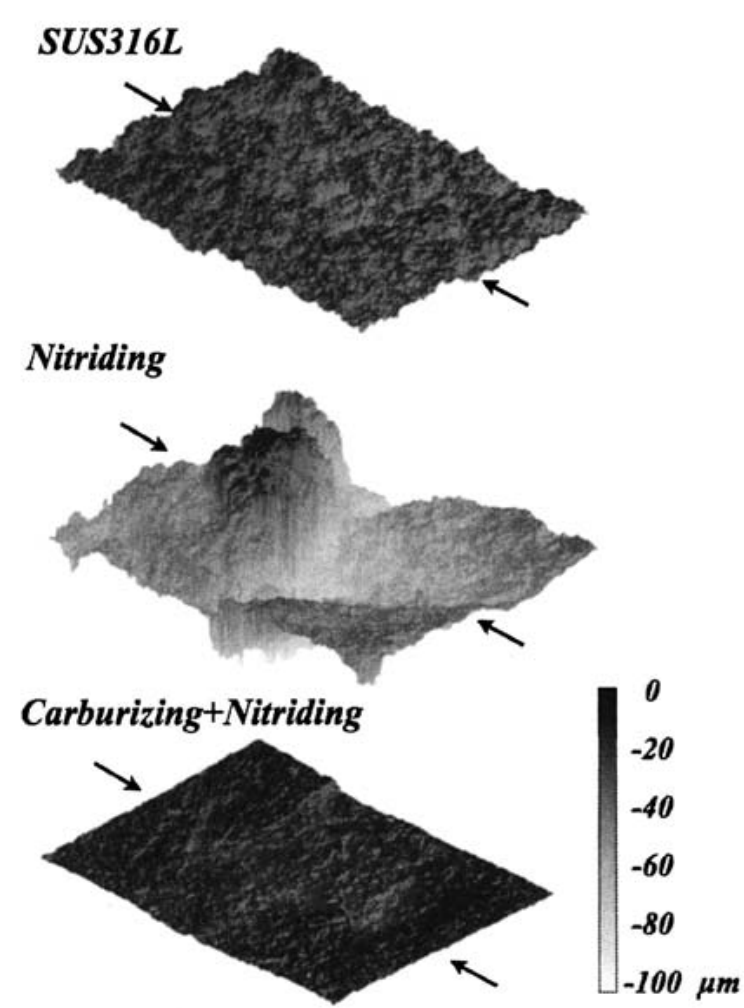

Fig. 6 3-D images of the surface for SUS316L and surface modified specimens after $10^{7}$ impacts by MIMTM.

一方，階層型処理の表面状態は平坦であり，最大深さは 約 $15 \mu \mathrm{m}$ で他と比較して損傷深さが浅く, 損傷が低減さ れていることを確認できる。

損傷試験後の試料中央部の断面写真を, 非損傷材と併 せて Fig. 8 に示す.ここで, 損傷試験後はき裂を明瞭に するため電解エッチングを施してある. SUS316L は, ピッ 


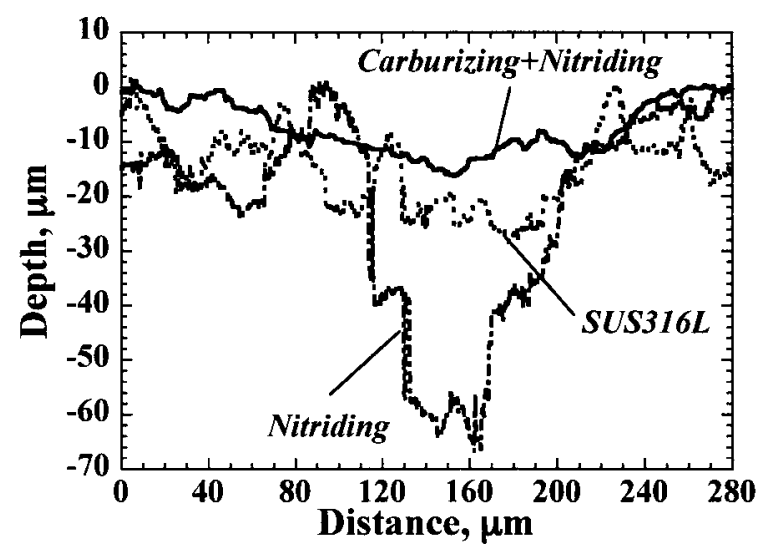

Fig. 7 Depth profiles of SUS316L and surface modified specimens after $10^{7}$ impacts by MIMTM.

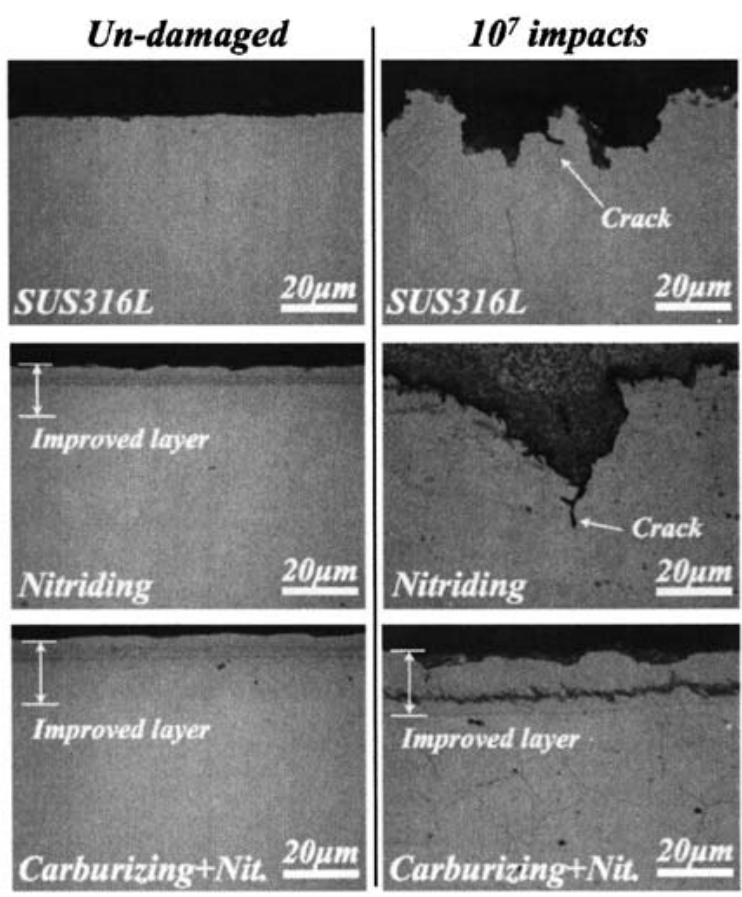

Fig. 8 Micrographs of pitting damage for SUS316L and surface modified specimens before and after $10^{7}$ impacts in cross section.

ト底周囲にき裂が観測された。これは，繰返し衝撃力が 負荷されることによって生じた疲労き裂であると考えられ る。また，このき裂は粒内および粒界のどちらにも観測さ れた。プラズマ窒化は, 試験前の画像から確認できる厚 さ $15 \mu \mathrm{m}$ 程度の改質層をほとんど確認できない. ここで, 画像より確認できる改質層厚さが，前述の全硬化層厚さ と異なるのは，画像では確認できない拡散層が存在する ためと考えられる. $10^{6}$ 回では, 改質層の残存が確認され たが, 衝撃回数の増加に伴い, 改質層表面が損傷し, 改 質層表面に生じたき裂が基材へと伝ぱし，結果として非 処理材以上の損傷深さに至ったと考えられる。一方，階 層型処理では, $10^{7}$ 回試験後でも改質層の残存が確認で き，階層処理による損傷抑制効果を確認できる。なお， 写真中の改質層に見られる水平方向の線は，エッチング によって明瞭になった研磨痕であり，き裂とは異なる。

\section{$4 \cdot 2$ 疲労強度}

SUS316L，プラズマ窒化および階層型処理における非 損傷材の疲労曲線を Fig. 9 に示す。ここで, 縦軸は最外 皮応力の最大值，横軸は破断までの繰返し数である。ま た，直線の傾斜部は，各試験応力における最低破断回数 を用いて対数近似し，疲労限度は，未破断応力と最小破 断応力の平均值とした，プラズマ窒化は，ピッティング 損傷が顕在化するまでの期間 , 即ち潜伏期長さの増長効 果が認められたが，疲労強度では，塑性域を含む低サイ クル領域で，わずかな強度低下が認められる。一方，高 サイクル領域では非処理材と同等か，わずかに強化され る傾向が見られる。階層型処理は，低サイクル領域では プラズマ窒化と同様にわずかな疲労強度の低下が認めら れるが，高サイクル領域ではプラズマ窒化以上の疲労強 度の向上が認められる.

$10^{7}$ 回損傷試験後の疲労曲線を Fig. 10 に示す. SUS 316L は，非損傷材と比較して疲労限度がわずかに低下し た。これは，107 回損傷付加後の SUS316Lでは局所的な 塑性変形が支配的であることから，ピッティング損傷付 加によりピット底に応力集中が発生したためと考えられ る。プラズマ窒化は，ピッティング損傷による疲労強度 の低下が SUS316L と比較して顕著であり，疲労限度は， 同衝撃回数のピッティング損傷付加後の SUS316L 以下

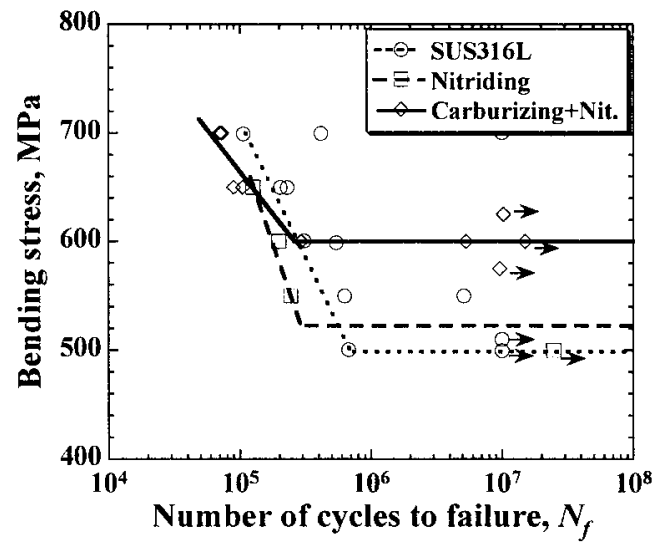

Fig. $9 S$ - $N$ curves for SUS316L and surface modified specimen without pitting damage.

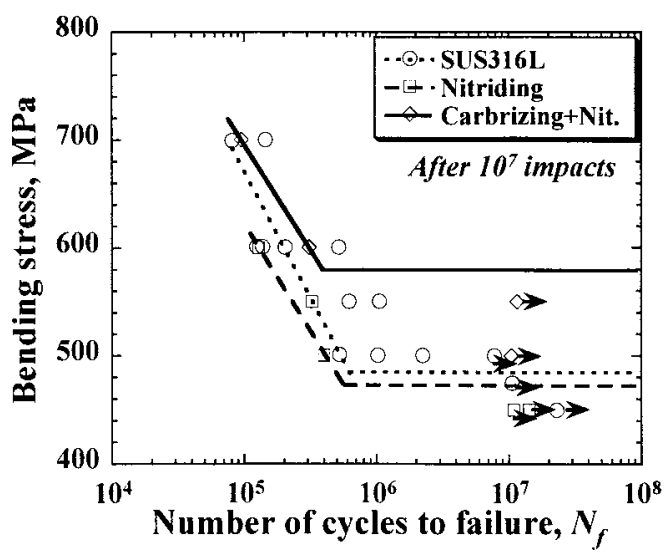

Fig. $10 S-N$ curves for SUS316L and surface modified specimens after $10^{7}$ impacts by MIMTM. 
まで低下した。これは，損傷後の断面観察で確認された 基材部まで到達する深いピット部に応力集中が生じたた めと考えられる。一方, 階層型処理は, ピッティング損 傷付加により非損傷材と比較してわずかに瘦労強度の低 下が認められるが，損傷付加後も SUS316L の非損傷材以 上の疲労限度を有する。これは，階層型処理によりピッ ティング損傷付加後においても改質層が残存しているた めである.

\section{5 考察}

\section{$5 \cdot 1$ 疲労破面の SEM 観察}

SEM による疲労破面の観察結果を Fig. 11 に示す。こ こで, SUS316L および皆層型処理は最外皮応力の最大值 が $650 \mathrm{MPa}$ ，プラズマ窒化材は $600 \mathrm{MPa}$ 試験時の破面で ある。また，図中の矢印は，疲労き裂の起点であり，写 真右は, 破線部分の拡大像である. SUS316L は, 疲労き 裂の起点が一箇所であるのに対して，プラズマ窒化拉よ び階層型処理では，複数起点による破壊が見られた。ま た，プラズマ窒化および皆層型処理では，改質層部分の 破面は平坦であり，ぜい性的な破面であることが確認で きる，窒化層は高硬度であるがもろく，容易にき裂が進 展するためと推測できる。また，この表層部で生じたき 裂を起点として応力集中が生じ，基材部へき裂が進展す るため, 高応力が負荷される低サイクル領域では, 非処 理材と比較して疲労強度が低下し, 窒化層にき裂が生じ ない低応力負荷の領域では，疲労強度が向上したと推測 できる，写真は，低サイクル疲労破面であり，プラズマ 窒化と階層型処理との顕著な差は確認できないが，両者 とも改質層と基材界面にき裂やはく離は見られず，また，
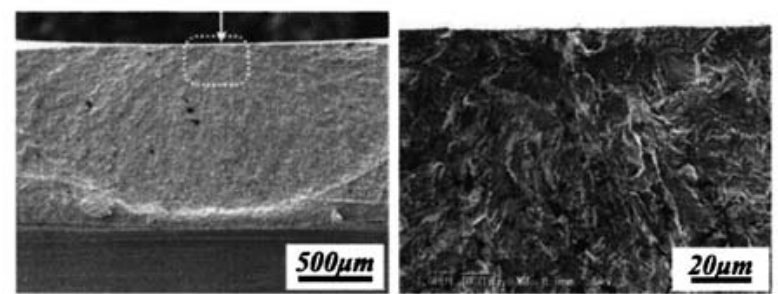

(a) SUS316L ,650 MPa
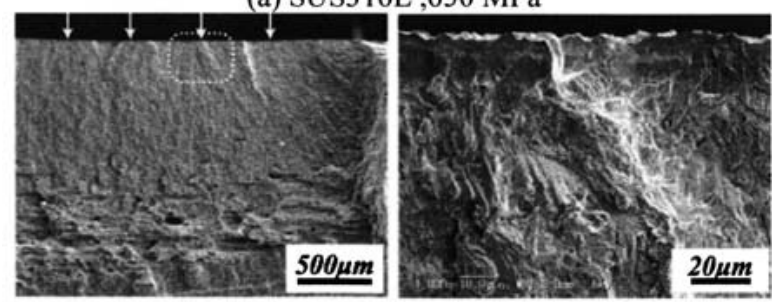

(b) Nitriding, $600 \mathrm{MPa}$

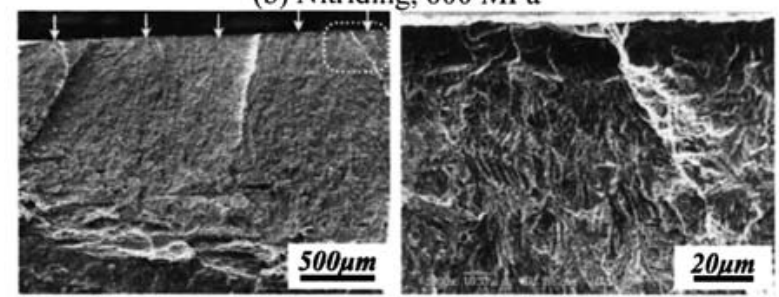

(c) Carburizing + Nitriding, $650 \mathrm{MPa}$

Fig. 11 SEM images of fracture surface without pitting damage.
疲労き裂の起点は表面であることから，充分な界面強度 を有していることが分かる。

$10^{7}$ 回損傷付加後の疲労破面を Fig. 12 に示す。写真 はいずれも最外皮応力の最大值が $600 \mathrm{MPa}$ の破面である. SUS316L では，複数の起点からき裂が伝ぱしたことによ り生じた破面上の段差を確認できる。起点を拡大すると， ピット底には，ピッティング損傷によって形成されたと 考えられる長さ約 $15 \mu \mathrm{m}$ のき裂が見られ，このき裂を起 点として疲労き裂が伝ぱしたことが分かる。プラズマ窒 化材は, SUS316L と同様に複数の起点からき裂が進展し たことを確認できる，起点部を拡大すると，起点は基材 部に貫通する局所化したピットの底であること，また， 非損傷材に見られたぜい性的な改質層部分が存在しない ことが確認できる。一方，階層型処理は，複数起点によ る破面上の段差は認められず，試料の端部近傍から広が る放射状模様が確認できる。また，起点部を拡大すると， 比較的平坦である $15 \mu \mathrm{m}$ 程度の改質層の残存を確認でき る。起点は，ピッティング損傷により形成されたと考え られるピット底の長さ $10 \mu \mathrm{m}$ 程度のき裂である.

\section{$5 \cdot 2$ 階層型処理による応力分布の変化}

これまでに得られた実験事実を踏まえ，改質層の力学 特性分布が衝撃負荷時の応力分布に与える影響について, 数值解析による検証を行った。

数值解析には，オイラー・ラグランジェの相互作用を 扱うことのできる，衝突解析コード，AUTODYN 2D ${ }^{12)}$ を用いた。キャビテーション気泡崩壊時に発生するマイ クロジェットが壁面に衝突することによるピッティング 損傷形成を模擬するために，マイクロジェットに見立て
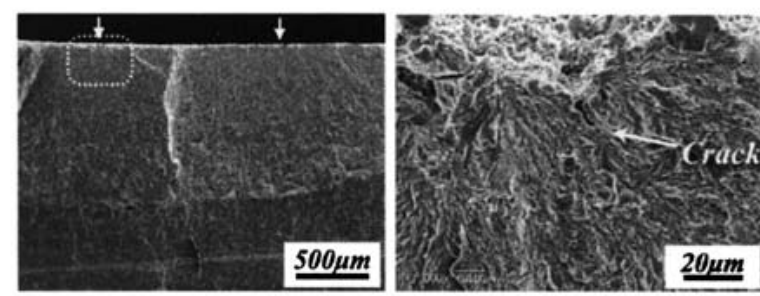

(a) SUS316L, $600 \mathrm{MPa}$

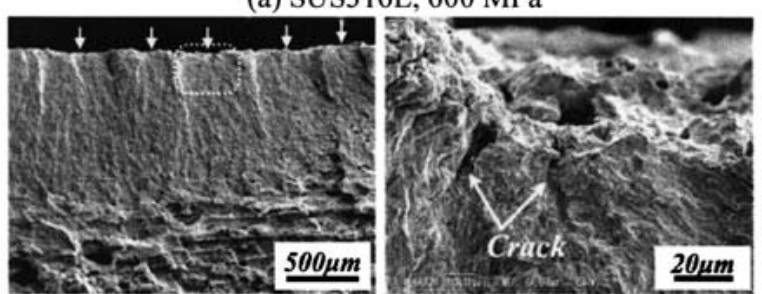

(b) Nitriding, $600 \mathrm{MPa}$

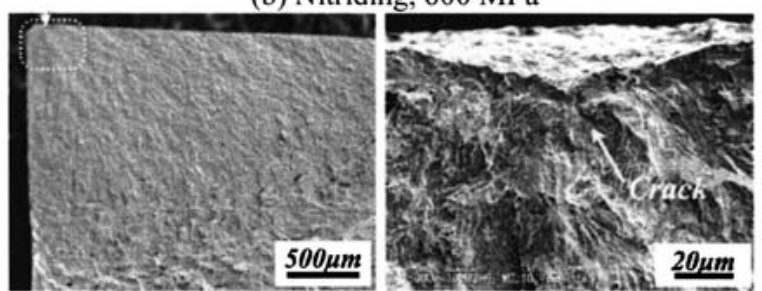

(c) Carburizing + Nitriding, $600 \mathrm{MPa}$

Fig. 12 SEM images of fracture surface after $10^{7}$ impacts by MIMTM. 
た水銀球を固体壁面に衝突させるモデルを作成した。水 銀の構成式は Rankine-Hugoniot, ${ }^{13)}$ 固体壁は，Johnson$\mathrm{Cook}^{14)}$ の構成式を用いた。モデル体系打よび境界条件 は，既報7)と同様である. Fig. 13 に解析モデルを示す。 ここで，モデルは，表面改質層を想定して，基材部の降 伏応力 $\sigma_{\mathrm{y}}(200 \mathrm{MPa})$ の 10 倍とした 2 層構造モデルおよ び，階層型表面改質処理を想定して，表層から基材にか けて階層状 $\left(10 \sigma_{\mathrm{y}}, 8 \sigma_{\mathrm{y}}, 6 \sigma_{\mathrm{y}}, 4 \sigma_{\mathrm{y}}, 2 \sigma_{\mathrm{y}}\right)$ の力学特性を持た せた 6 層構造モデルを作成した。液滴球形 $50 \mu \mathrm{m}$ として, SUS316L において MIMTM560W 試験時に形成されるピッ トの深さ／半径の比を再現する $300 \mathrm{~m} / \mathrm{s}^{7)}$ で水銀球を衝突 させた場合の改質層と基材の界面で生じるせん断応力の 時刻歴応答を Fig. 14 に示す。罒は，改質層厚さ $10 \mu \mathrm{m}$ のモデルにおける界面のせん断応力である。衝突後約 $0.1 \mathrm{~ms}$ で最大值に達し，その後減衰する。階層型表面改 質処理を想定した 6 層構造モデルでは，2 層構造モデル と比較して, せん断応力が $1 / 3$ 以下に低減されているこ とが分かる．また，改質層厚さを変化させた場合の時刻 歴応答より求めた, 改質層厚さと最大せん断応力の関係 を Fig. 15 に示す. 2 層構造モデルでは, 改質層厚さの 増加に伴い，せん断応力が低減することが分かる。また， 6 層構造では, 改質層厚さ約 $50 \mu \mathrm{m}$ で 2 層構造の約 $150 \mu \mathrm{m}$ 厚さと同等のせん断応力まで低減できることが分 かる.

従って，階層型処理が，窒化処理と比較して適度な損 傷抑制効果が得られたのは，なだらかな表面の硬度分布 が改質層と基材の界面に発生するせん断応力を抑制し，

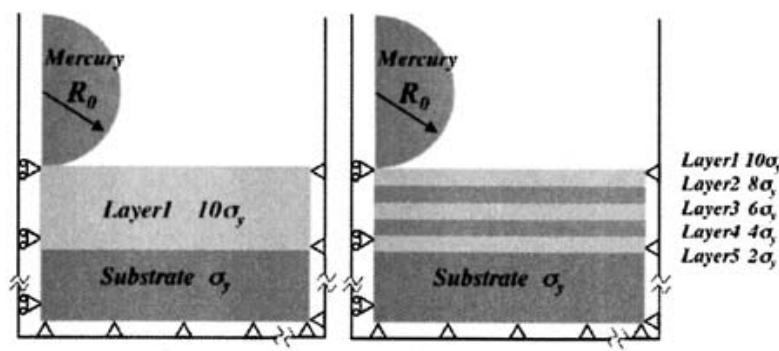

Fig. 13 Schematic illustration of FEM models for droplet impact analysis.

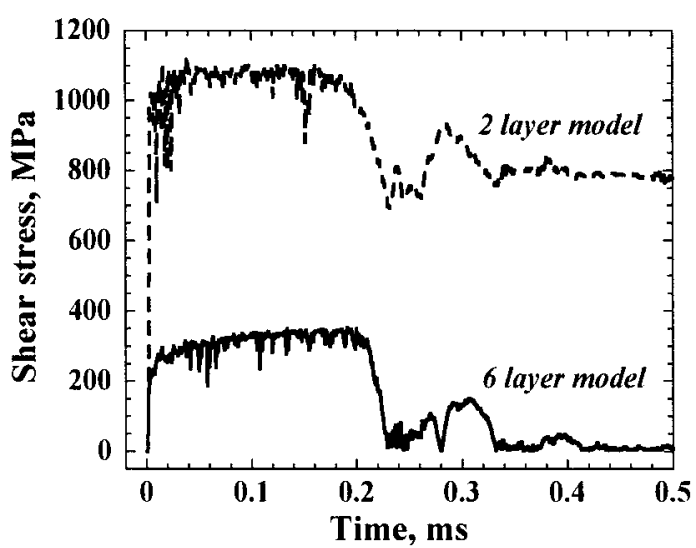

Fig. 14 Time response of shear stress in interlayer of between the substrate and the modified layer.

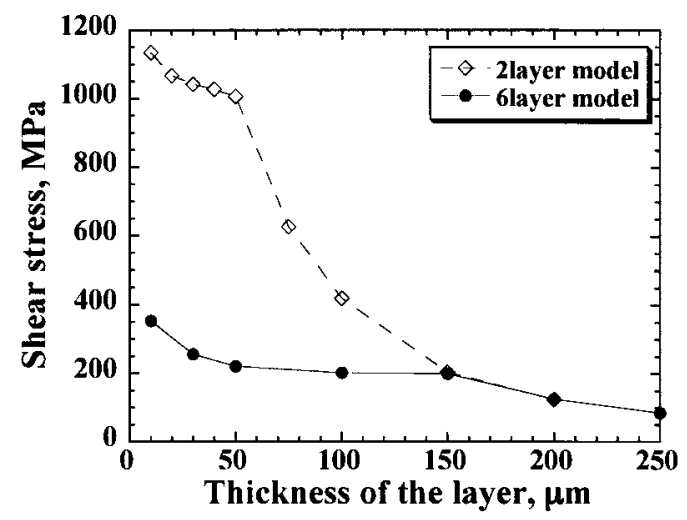

Fig. 15 Relationship between the maximum shear stress and thickness of the modified layer.

き裂やはく離が生じにくくなったためと考えられる。ま た，階層型処理は，単層の改質処理と比較すると，せん 断応力低減打よび界面強度の観点から効率良くピッティ ング損傷形成を抑制できることが推測できる。

\section{6 結 論}

核破砕中性子源の水銀ターゲット容器内壁に適用が検 討されている表面改質処理に関して，水銀キャビテーショ ンによるピッティング損傷抑制，および繰返し応力負荷 に伴う疲労強度向上の観点から, 最適な処理条件を検討 した。その結果，以下の結論が得られた。

ステンレス鋼に対して，低温でプラズマ浸炭処理を施 した後にプラズマ窒化処理を施すことで，炭素の拡散層 を拡大し, 改質表層から基材部にかけてなだらかな硬度 の傾斜を有する階層型表面改質処理を考案し，さらに， 処理温度および処理時間の検討を行い，最適な処理条件 を導出した

考案した階層型処理を, ターゲット容器構造材である SUS316L に適用し，107 回のピッティング損傷試験を行 い，階層型処理によるピッティング損傷抑制効果を確認 した。さらに, 疲労試験から, 階層型処理により疲労限 度が向上すること, $10^{7}$ 回のピッティング損傷負荷後も SUS316L の非損傷材以上の瘦労限度を有することを確認 した.

\section{参 考 文 献}

1) Y. Ikeda, "1-MW pulsed neutron source (JSNS) of J-PARC", Neutron News, Vol.16, No.1, pp.20-24 (2005).

2 ) L. K. Mansur and J. R. Haines, "Status of Spallation Neutron Source with focus on target materials”, Journal of Nuclear Materials, Vol.356, pp.1-15 (2006).

3 ) G. S. Bauer and H. Ullmaier, "Materials related R \& D work for the ESS target station”, Journal of Nuclear Materials, Vol.318, pp.26-37 (2003).

4 ) M. Futakawa, H. Kogawa, R. Hino, H. Date and H. Takeishi, "Erosion damage on solid boundaries in contact with liquid metals by impulsive pressure injection”, International Journal of Impact Engineering, Vol.28, pp.123-135 (2003).

5 ) T. Naoe, M. Futakawa, T. Oi, T. Wakui and Y. Motohashi, 
"Fatigue strength degradation by pitting damage", Journal of The Society of Material Science Japan, Vol.54, No.11, pp.1184-1190 (2005).

6 ) M. Futakawa, T. Naoe, T. Kogawa, C. C. Tsai and Y. Ikeda, "Pitting damage formation up to 10 million cycles -Off line test by MIMTM-", Journal of Nuclear Science and Technology, Vol.40, pp.895-904 (2003).

7 ) T. Naoe, M. Futakawa, T. Oi, S. Ishikura and Y. Ikeda, "Pitting damage evaluation by liquid/solid interface impact analysis”, Journal of The Society of Material Science Japan, Vol.54, No.11, pp.1184-1190 (2005).

$8)$ T. Naoe, T. Oi, H. Kogawa, T. Wakui and M. Futakawa, "Pitting damage morphology of surface modified material -Damage suppression by surface hardening treatment-”, Journal of The Society of Material Science Japan, Vol.57, No.2, pp.159-166 (2008).

9) F. H. Harris, "Case Depth-An Attempt at a Practical
Definition”, Metal Progress, Vol.44, No.2, pp.265-272 (1943).

10) J. D. Fast and M. B. Verrijp, "Diffusion of nitrogen in iron", Journal of The Iron and Steel Institute, Vol.183, pp.24-27 (1954)

11) M. Futakawa, H. Kogawa, C. C. Tsai, S. Ishikura and Y. Ikeda, "Off-line tests on pitting damage in mercury target", JAERI-Research 2003-005, pp.27-53 (2003) Japan Atomic Energy Research Institute.

12) Century Dynamics, inc., "AUTOODYN Theory Manual”, Ver.4.1, (2000) Century Dynamics, inc.

13) Group GMX-6, "Selected Hugoniots, LA-4167-MS”, Los Alamos Scientific Lab. (1969).

14) G. R. Johnson and W. H. Cook, "A constitutive model and data for metals subjected to large strains”, High Strain Rates and High Temperatures, Presented at the Seventh International Symposium on Ballistics, The Hague, The Netherlands, April (1983). 